\title{
Study on Upgradation in Carburizing Technologies for steel strength
}

\author{
${ }^{\text {a}}$ Saadat Ullah Khan Suri, ${ }^{\mathrm{a}}$ Mohammad Siddique, ${ }^{\mathrm{b}}$ Abdul Sattar Jatoi, ${ }^{\mathrm{c}}$ Asad Ullah Baloach \\ a Department of Chemical Engineering BUITEMS, Quetta, Pakistan \\ ${ }^{b}$ Department of Chemical Engineering DUET, Karachi, Pakistan \\ ${ }^{\mathrm{c}}$ Mir Chakar Khan Rind University Sibbi, Pakistan
}

\begin{abstract}
Carburizing technologies are used to provide strength on low quality metals. This technology is being developing with novel improvements significantly. The carburizing process consists of, first releasing Carbon monooxide from charcoal material and then transfers carbon to raw metal. There are favorable upgradation in these technologies from researchers which have a paramount industrial importance. In Vacuum gas carburizing, the steel metal is carburized with (Acetylene and Propane) gases. These gases are at low pressure and high temperature. The results show that the metal is $\mathbf{1 . 5}$ times harder than its raw form. There are also used mathematical models to validate the results. It used gas and solid phases for validation. In pulse carburizing, carbon diffusion on steel is investigated with heat treatment. This process includes several carburizing stages. This process is based on Darken bi velocity and drift velocity. It accounts to demonstrate the kinetics of carbon transfer on steel surface. This design is very useful by regarding carburizing time for this process design. In Plasma carburizing, the mixtures of gases are used to harden the steel. The carburizing temperature was varied in cementite and martensitic. The favorable results show that these specimens have (Lower surface roughness, higher surface hardness and Low wear rate). It is a most novel diffusion controlled novel process till the present time. The carburized metal is used in industry by including (Turbine gears and Air craft engine). Henceforth, It is of great importance to study the carburizing technologies for providing better strength on metal.
\end{abstract}

Keywords: Vacum carburizing, Pulse Carburizing, Plasma Carburizing, Cementite and Martensite.

Date Received 24-07-2019

Date Accepted 25-12-2019

Date Published 31-12-2019

\section{INTRODUCTION}

The surface of the metal materials can be made stronger by using carburizing processes. In carburizing process, the Carbon monoixide (CO) gas is released by using charcoal as the medium and surface of the metals are carburized simultaneously. There has been further improvements are developed in the carburizing processes that have upgraded the steel strength significantly [1-4].

The steel carburizing is a thermo-chemical process that starts upon heat treatment of steel surface with the carbon. It is due to the diffusion of carbon on the steel surface. It upgrades the quality of steel by regarding mechanical and chemical characteristics. The up gradation in steel quality counts on the factors by including Carbon (Distribution, Depth and Concentration) [5-7].

Acetylene $\left(\mathrm{C}_{2} \mathrm{H}_{2}\right)$ and Propane $\left(\mathrm{C}_{3} \mathrm{H}_{8}\right)$ is used in petro chemical industries as the feedstock by producing carbon and its oxides. The pyrolysis of propane generates the reactions, which give valuable products at $\left(900{ }^{\circ} \mathrm{C}-1050{ }^{\circ} \mathrm{C}\right.$ and 2 mbar) operating conditions. The Carbon deposited from diffusion on the steel surface hardens it. The Carbon concentration increases to $1 \%$ by mass. The amount of carbon deposited on the steel surface is interlinked with the partial pressure of the carburizing gas. Furthermore, the deposition of higher hydrocarbon on steel surface is a challenging issue that needs to get addressed till the present time [8-10]. 
The gas carburizing process developed in 1910 in America. The Propane $\left(\mathrm{C}_{3} \mathrm{H}_{8}\right)$ and Butane $\left(\mathrm{C}_{4} \mathrm{H}_{10}\right)$ are fed in furnace. Their products are $\mathrm{CO}, \mathrm{CO}_{2}$ and $\mathrm{H}_{2} \mathrm{O}$ that react with metals surface to increase strength. These producer gases act as oxide of metals and cause corrosion to the steel surface that leads to degradation [11-14].

In 1968, C.I. Hayes invented Vacum gas carburizing. It is the replacement for the gas carburizing process. Its main objective is to reduce the carburizing time and cost of energy. The major advantage of this process is that it prevents oxidation on the steel surface. He supplied Acetylene $\left(\mathrm{C}_{2} \mathrm{H}_{2}\right)$ and Propane $\left(\mathrm{C}_{3} \mathrm{H}_{8}\right)$ in the furnace at the temperature $927{ }^{\circ} \mathrm{C}$ to $1027{ }^{\circ} \mathrm{C}$. There was increased in carbon transfer due to high temperature. Thus, It was an advantage for steel strength. It is the focus of many researchers now [11-13].

The Acetone $\left(\mathrm{C}_{3} \mathrm{H}_{6} \mathrm{O}\right)$ concentration that is used to stabilize the Acetylene $\left(\mathrm{C}_{2} \mathrm{H}_{2}\right)$ (Transport, Storage and its effect on Pyrolysis reactions) needs effective investigation. The optimization in Vacuum gas carburizing process has the major focus on gaseous feed chemistry. So, there is a need to develop a simulated model which enables optimization of Acetylene $\left(\mathrm{C}_{2} \mathrm{H}_{2}\right)$ and Propane $\left(\mathrm{C}_{3} \mathrm{H}_{8}\right)$ pyrolysis reactions with computational fluid dynamics codes [14-15].

The optimization in gaseous feed rate leads to the uniform carburizing in Vacuum gas carburizing process. There are numerical methods, which are quite effective to demonstrate the physical phenomena in Vacuum gas carburizing process for steel strength. These models describe the physical process of Vacuum gas carburizing that takes account for both gas and solid phases. It summarizes towards the validation of results from experiments by having optimization in process [16-17].

The new developed Plasma carburizing is a process which upgrades the physical properties of steel. The oxide film $\left(\mathrm{Cr}_{2} \mathrm{O}_{3}\right)$ deposited on steel leads to a decrease in adhesion from protective coating at steel surface. The high quality steel is generated by using low temperature plasma carburizing. It proves to be corrosion and wear resistant. The M50NiL steel has surface harden microstructure that can be used in Aircraft engine. This is a novel development in carburizing process [18-21].

The present research study is focused on technologies, which are used to strengthen the steel with their optimized parameters by considering (Gaseous feed chemistry, Temperature and Pressure).

\section{Literature Study}

\subsection{Vacum Gas Carburizing}

Khan did the research work on the Acetylene $\left(\mathrm{C}_{2} \mathrm{H}_{2}\right)$ pyrolysis for vacuum gas carburizing in Tubular flow reactor. The main purpose of the investigation is to compare the simulation and experimental results. In Tubular flow reactor, there is attained $650^{\circ} \mathrm{C}$ to $1050{ }^{\circ} \mathrm{C}$ temperature at feed partial pressure of 10 mbar and 20 mbar respectively. There employed 1.6 bar of partial pressure with kinetic mechanism which comprise of 9 reactions [22].

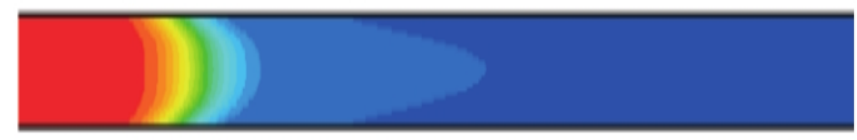

Fig. 1 Acetylene mole fraction in tubular flow reactor simulation at $900{ }^{\circ} \mathrm{C}$ and 20 mbar partial pressure conditions.

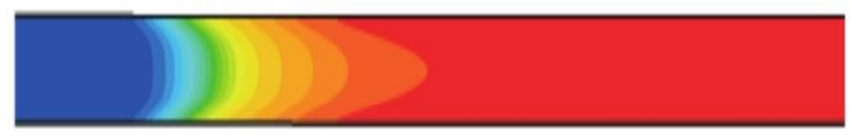

Fig. 2 Contour of mole fraction of Carbon through flow reactor simulation at $900{ }^{\circ} \mathrm{C}$ and 20 mbar partial pressure conditions.

The figures 1 and 2 demonstrate the mole fractions of Acetylene $\left(\mathrm{C}_{2} \mathrm{H}_{2}\right)$ and Carbon in Tubular flow reactor respectively. It is examined from the simulation of Tubular flow reactor that Acetylene $\left(\mathrm{C}_{2} \mathrm{H}_{2}\right)$ concentration decreases in $\mathrm{x}$-direction as the reaction goes forward. The Carbon concentration increases with increase in time from the middle zone of reactor in $\mathrm{x}$-direction. Henceforth, there is increase in concentration of Carbon which leads to attain strength in steel metal.

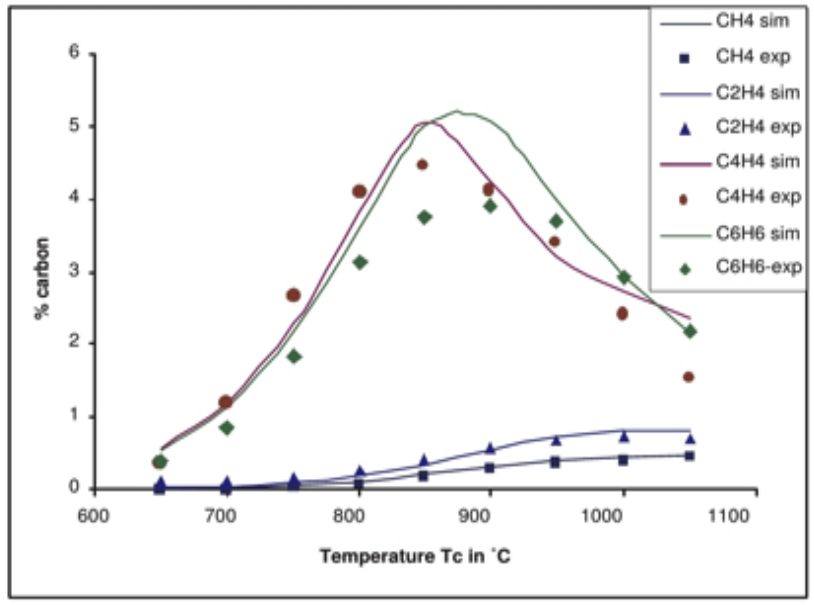

Fig. 3 Illuatration on simulation and experimental results at 20 mbar acetylene partial Pressure.

The Figure 3 demonstrates the comparison between simulation and experimental results of Acetylene $\left(\mathrm{C}_{2} \mathrm{H}_{2}\right)$ at $20 \mathrm{mbar}$ of partial pressure condition. The formation of hydrocarbon products Methane $\left(\mathrm{CH}_{4}\right)$, Ethylene $\left(\mathrm{C}_{2} \mathrm{H}_{4}\right)$ during pyrolysis of Acetylene $\left(\mathrm{C}_{2} \mathrm{H}_{2}\right)$ are simulated to get the experimental results validation. The slight differences of $0.3 \%, 2.5 \%$ and $0.7 \%$ for Ethylene $\left(\mathrm{C}_{2} \mathrm{H}_{4}\right)$, Cyclobutadiene $\left(\mathrm{C}_{4} \mathrm{H}_{4}\right)$ and Benzene $\left(\mathrm{C}_{6} \mathrm{H}_{6}\right)$ are observed from simulation with experimental results respectively. Overall, It determines the increase in Carbon concentration with increase in temperature from $650{ }^{\circ} \mathrm{C}$ to $1050^{\circ} \mathrm{C}$ at $20 \mathrm{mbar}$ of partial pressure conditions.

\subsubsection{Reaction Mechanism}

The three major reactions, which results the Carbon formation and Hydrogen on steel surface are; 
Reaction 1: $\mathrm{C}_{2} \mathrm{H}_{2}+\mathrm{H}_{2} \rightarrow \mathrm{C}_{2} \mathrm{H}_{4} \quad$ Ei $(\mathrm{kJ} / \mathrm{mol})=103.0$ Reaction 2: $\mathrm{C}_{4} \mathrm{H}_{4}+\mathrm{C}_{2} \mathrm{H}_{2} \rightarrow \mathrm{C}_{6} \mathrm{H}_{6} \mathrm{Ei}(\mathrm{kJ} / \mathrm{mol})=64.5$ Reaction 3: $\mathrm{C}_{6} \mathrm{H}_{6} \rightarrow 6 \mathrm{C}(\mathrm{s})+3 \mathrm{H}_{2} \quad \mathrm{Ei}(\mathrm{kJ} / \mathrm{mol})=75.0$ These reactions show the formation of carbon on steel in Tubular flow reactor. The reaction mechanism was modeled in Ansys-fluent. These reaction are implemented in user defined function at Ansys-fluent. The activation energy derived from Arrhenius equation parameters, which becomes low as the reactions get completed [23].

\subsubsection{Vacum Gas Carburizing under Propane Pyrolysis:}

Khan and Bajhor did the research work on Propane $\left(\mathrm{C}_{3} \mathrm{H}_{8}\right)$ pyrolysis reactions both from experimental and modeling techniques. Propane $\left(\mathrm{C}_{3} \mathrm{H}_{8}\right)$ pyrolysis is done in Plug flow reactor at operation conditions $\left(640{ }^{\circ} \mathrm{C}-1010{ }^{\circ} \mathrm{C}\right.$ and 8 mbar). The gas atmospheric conditions are similar to Vacuum gas carburizing of steel [24].

The Nitrogen $\left(\mathrm{N}_{2}\right)$ gas used as an inert medium to prevent oxidation. After the Propane $\left(\mathrm{C}_{3} \mathrm{H}_{8}\right)$ pyrolysis reactions, the product gas collected for gas chromatography. Then, simulation of gas phase reactions in 1D and 2D are done.

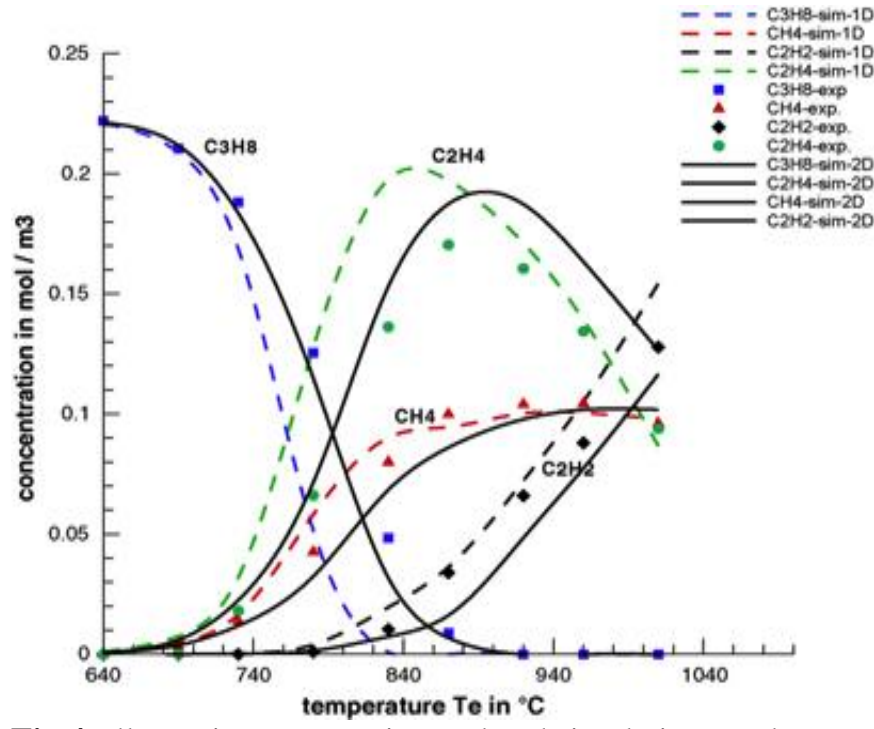

Fig.4 Illustration on experimental and simulation results From pyrolysis of Propane.

The figure 4 demonstrates the difference between simulation and experimentation results. There are 1D and 2 D simulations, which show slight variation among each other. The reaction initiated at $640{ }^{\circ} \mathrm{C}$ and Propane $\left(\mathrm{C}_{3} \mathrm{H}_{8}\right)$ composition was maximum. The products by including Acetylene $\left(\mathrm{C}_{2} \mathrm{H}_{2}\right)$, Methane $\left(\mathrm{CH}_{4}\right)$ and Ethylene $\left(\mathrm{C}_{2} \mathrm{H}_{4}\right)$ increases upto $0.14 \%, 0.9 \%$ and $0.16 \%$ mole percentages respectively. There observed $10 \%$ deviation in $1 \mathrm{D}$ and $2 \mathrm{D}$ simulation results for Popnane $\left(\mathrm{C}_{3} \mathrm{H}_{8}\right)$, Methane $\left(\mathrm{CH}_{4}\right)$, Acetylene $\left(\mathrm{C}_{2} \mathrm{H}_{2}\right)$ and Ethylene $\left(\mathrm{C}_{2} \mathrm{H}_{4}\right)$.

Consequently, the pyrolysis of Propane $\left(\mathrm{C}_{3} \mathrm{H}_{8}\right)$ is studied under Vacuum gas carburizing condition of steel. Both simulation and experimental results are encouraging [25].

\subsection{Vacum Gas Carburizing reactive flow modelling:}

Yada and Watanbe did the research work on Vacuum gas carburizing to provide strength on metals. They used Acetylene $\left(\mathrm{C}_{2} \mathrm{H}_{2}\right)$ and Propane $\left(\mathrm{C}_{3} \mathrm{H}_{8}\right)$ gases at low pressure and above $727{ }^{\circ} \mathrm{C}$ temperature. The results show that carburized metal is 1.5 times stronger than raw metal. The carburized metal is used in an industrial application on gears of gas turbine to prevent rotation and contact situation [26].

They used mathematical simulation of Vacuum gas carburizing with Acetylene $\left(\mathrm{C}_{2} \mathrm{H}_{2}\right)$ gas diluted in Argon gas. It takes the gas and solid phases of Vacuum gas carburizing to get an interaction. There carried out the surface reaction on steel from carburizing process. The carbon transfer is calculated from specific user defined function in Ansys-Fluent 13.0. The major objective of this work is to elaborate that how well proposed mathematical simulation approach can better demonstrate the physical phenomena and optimized parameters of Vacuum gas carburizing process.

In experimental setup, there is a heat chamber in which Acetylene/Argon gas mixtures are fed in quartz pipe chamber. The deposited carbon is measured by using electronic balance before and after carburizing.

The mathematical simulation results show the mole fractions of Hydrogen and Acetylene in gas and carbon mass fraction on the metal. It exhibits the computational fluid dynamics codes can provide an extended application on carburizing process as a unique tool.

The Vacuum gas carburizing consists of three stages;

(i) Boost stage

(ii) Diffusion stage

(iii) Cooling stage

Each Vacuum gas carburizing step is simulated and described as follows;

\subsubsection{Boost stage}

In boost stage, gas phase contacts with the surface of metal intensively. Therefore, Carbon releases and gets transfer on the solid metal surface. The schematic diagram of this process is shown in figure 5 below.

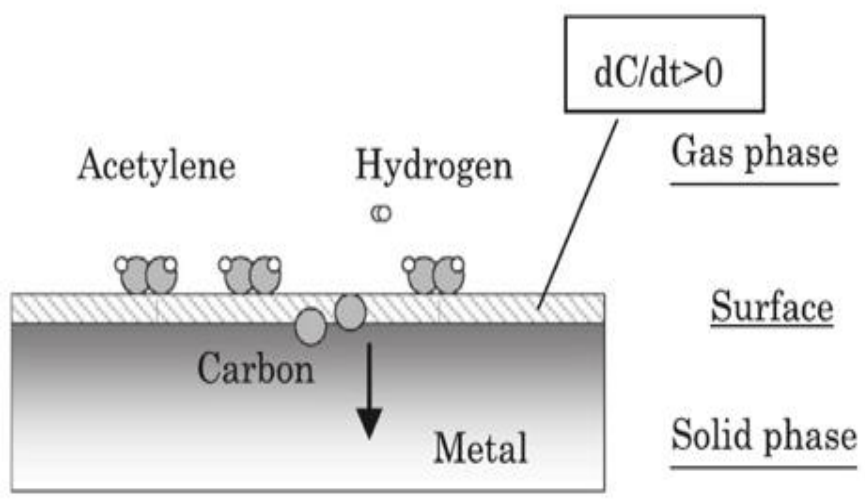

Fig. 5. Illustration on Carbon release and transfer on solid metal in boost stage of Vacuum gas carburizing.

The concentrations of solid phases are at non-equilibrium condition as demonstrated in figure 5.

\subsubsection{Diffusion stage}

The diffusion stage is second step in Vacuum gas carburizing by increasing the carburizing region. It facilitates the gas reactions on solid surface. After it, carbon transfers into it. The process diagram of this reaction is shown in below figure 6 . 


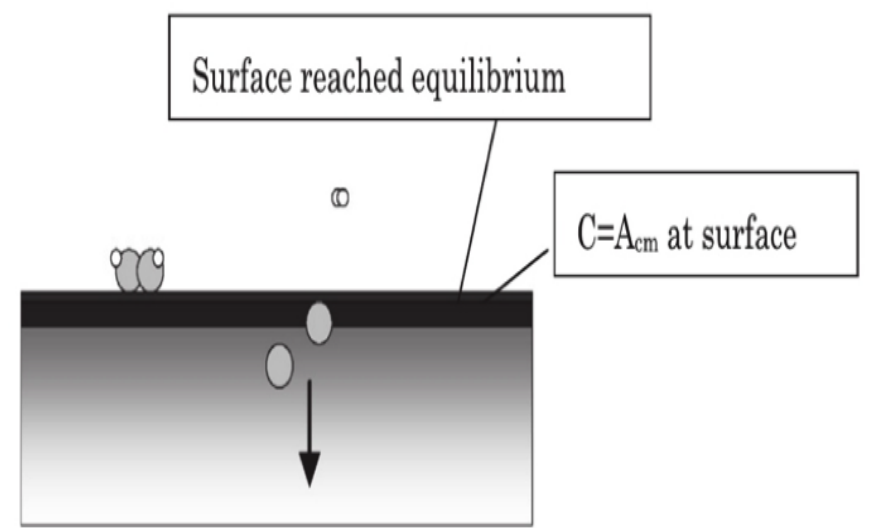

Fig. 6 Illustration in diffusion stage of Vacuum gas carburizing.

The figure 6 demonstrates the process in which Carbon diffuses on the solid surface. It can be calculated as the solid in gas phase in equilibrium with metal by using the diffusion equation through mathematical simulation code in Ansys-Fluent 13.0.

\subsubsection{Cooling stage}

In cooling stage, it is used to get Carbon fixed on the metal surface. The carburized metal is soaked into oil. Thereafter, the surface of metal achieves strength. The gas phase is empty as change observed in solid phase. The concentration gradient is low which shows slow cooling as demonstrated the figure 7 below.

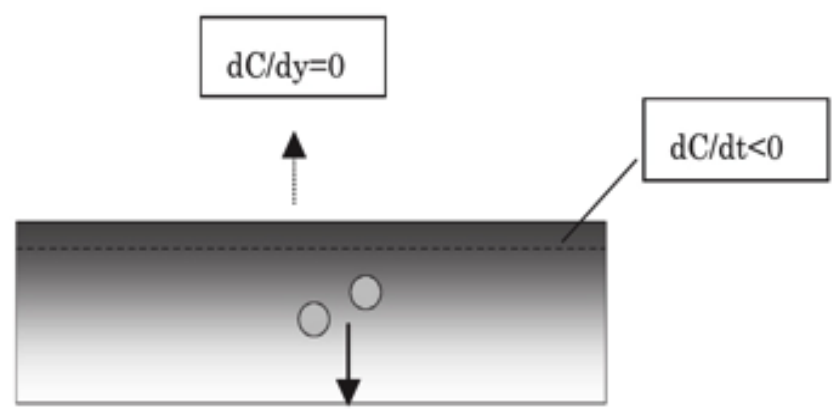

Fig. 7 Illustration on slow cooling stage in Vacum gas carburizing process.

As a result, the new mathematical simulation model in Ansys-Fluent 13.0 is able to demonstrate the fluid-solid interaction.

The slight limitation in experimental setup is that, this model corresponds to show the physical phenomena of Vacuum gas carburizing process.

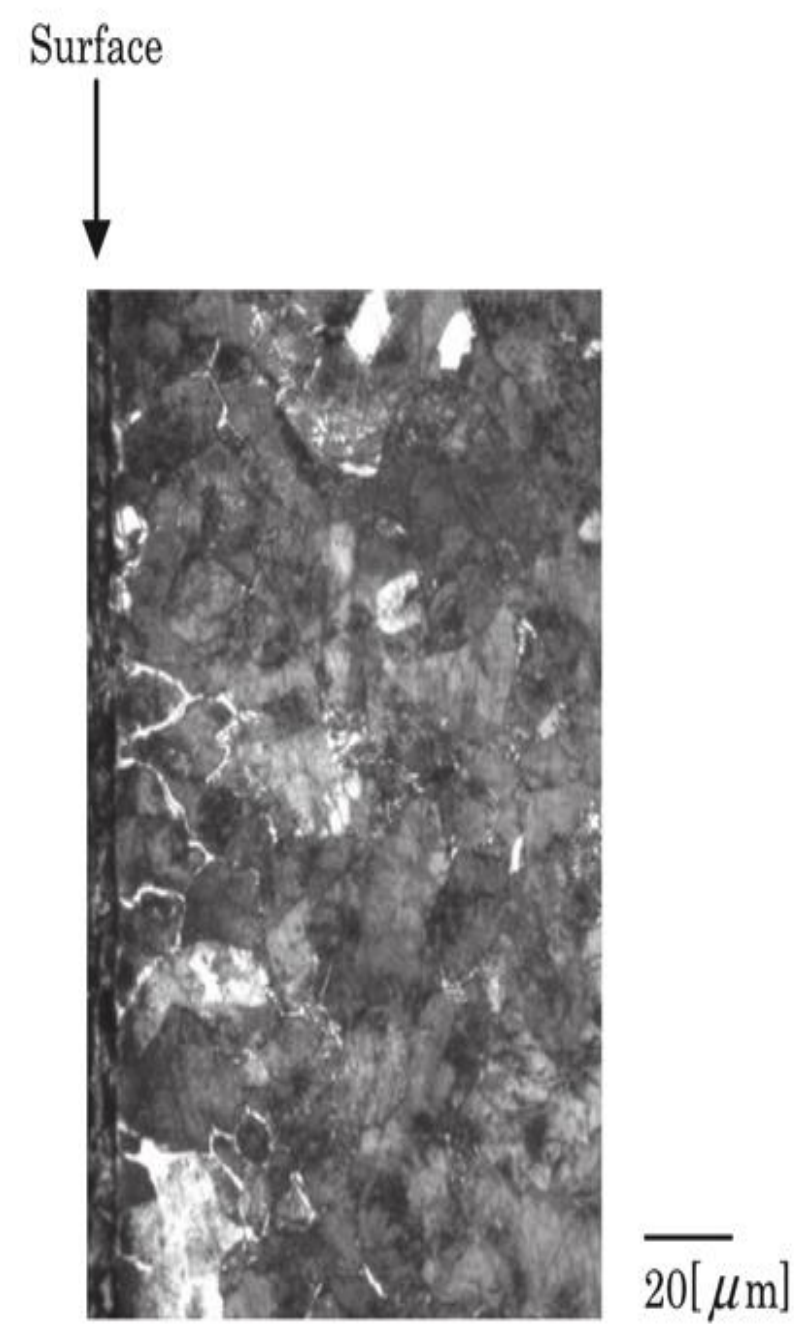

Fig. 8. Illustration on steel metal structure by using Vacum gas carburizing conditions through metallurgical microscope.

With the help of metallurgical microscope, mathematical results at the surface of steel are examined. The operating conditions for Vacum gas carburizing were at $1.3 \mathrm{kPa}$ with carburizing time of $36 \mathrm{~min}$. The steel metal characterized as pure pearlite and cementite from photograph. Carbon mass fractions; 0.765 and 6.689 (wt.\%) for pearlite and cementite respectively [27].

\subsection{Vacum Pulse Carburizing:}

Zajusz, Śmiech and Danielewski proposed a theory that postulates Vacuum pulse carburizing. This process carried out with the repetition in carburizing (Boost) stage. This model carries the Darken Bi- velocity that consists of diffusion and drift velocities. This Bi-velocity is applied to carburizing process, which model the carburizing process further [28].

This process evaluates the kinetics of Carbon transfer to the solid surface at variable conditions, which is significant for carburizing process.

Moreover, Vacuum pulse carburizing upgrades the mechanical characteristics of steel. There are still limitations in this method by regarding (Fundamental design and Mathematical modeling) methods. In this 
process, the carbon distribution on the steel surface subjected to pulse carburizing, is illustrated in under figure 9.

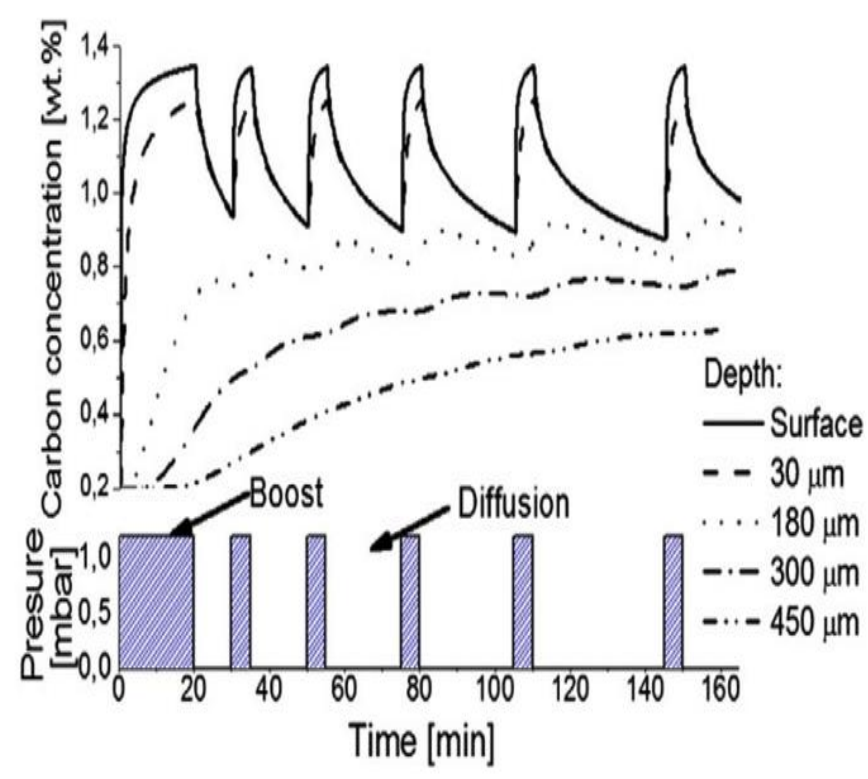

Fig. 9 Illustration on Carbon concentration distribution at Vacum pulse carburizing at $920{ }^{\circ} \mathrm{C}$.

In figure 9, the curves to represent Carbon at various depths are shown. A change in Carbon concentration with carburizing time is seen. The Carbon concentration recorded at various distances on the metal surface $(0,30$, $180,300,450) \mu \mathrm{m}$. It is evident from the results that the Carbon concentration increases with the time at $0.3 \mathrm{~mm}$ height. While in the middle of the surface, there is cyclic change in Carbon concentration; in (Boost and Diffusion) stages [29-32].

\subsection{Plasma Carburizing:}

Yang and Yan did the research work on Plasma carburizing of M50NiL steel with diffusion of Carbon. The Plasma carburizing process carried out in the mixtures of (Acetone and Hydrogen) gases at the temperature range of 400$550^{\circ} \mathrm{C}$. This process occurs from 4 to $12 \mathrm{~h}$ time duration. The effect of temperature treatment was measured by using (Optical microscope, Atomic force microscope, X-ray diffractometer, Micro- and nano-indenters, and Pin-on-disc tribometer)[33].

The experiments results are in agreement with the carburized surface layer of cementite and Carbon expanded martensite.
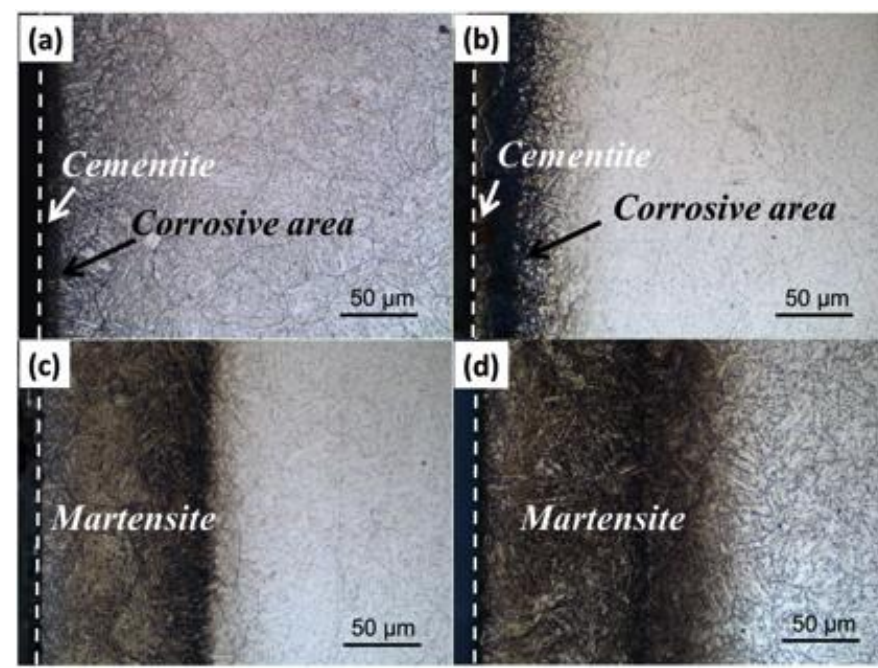

(d)

Fig.10 Illustraion on optical micrographs of steel specimens at different tempereature ranges (a) $400{ }^{\circ} \mathrm{C}$, (b) 450 ${ }^{\circ} \mathrm{C}$, (c) $500{ }^{\circ} \mathrm{C}$, (d) $550{ }^{\circ} \mathrm{C}$.

The figure 10 shows the steel specimens are carburized at different temperature ranges at constant time period of $8 \mathrm{~h}$. There is an observation that the temperature has an effect on thickness of modified Carbon layer. There is increase in thickness of carburized layer. The observed darkness is due to the etching effected from $400{ }^{\circ} \mathrm{C}$ to $450{ }^{\circ} \mathrm{C}$ of temperature. There are homogeneous surface layer of specimen which treated at 500 and $550{ }^{\circ} \mathrm{C}$. It is due to the integrated martensitic microstructure [34-37].

\section{Conclusions:}

There has been a rapid evolution in carburizing technologies for providing strength to steel metal.

1. The Vacum gas carburizing technologies helps in strengthing the steel. The carbon content plays the key role in it. The mathematical modeling elaborates the whole phenomena. The major problem in this process is the formation of tiny holes due to uniform carburizing. Additionaly, it benefits in running, energy cost and improved metal quality.

2. The Vacum pulse carburizing upgrades the mechanical characteristic of steel significantly. The optimized parameters are controlled with carefully monitoring of $\mathrm{Bi}$ velocity, Drift velocity and Carbon distribution for any subtle changes.

3. In Plasma carburizing, the effect of temperature on the surface characteristics of Cementitie and Mertensite is investigated. The results conclude that main phase on the surface layer formed during the process at $550{ }^{\circ} \mathrm{C}$. The Cementite developed with temperature treatment. The carburized layer on Cementite shows lower roughness and higher surface hardness.

\section{Acknowledgment}

The authors are grateful to the staff at department of chemical at BUITEMS, Quetta for their cooperation during research work.

\section{References}

[1] X. Zhang, P. Jiang, C. Zhang, B. Buhe, B. Liu and Y. Zhao, "Anticorrosion Performance of LDH Coating Prepared by $\mathrm{CO}_{2}$ Pressurization Method, 'International Journal of 
Corrision, vol. 1 pp. 1-10, 2018.

[2] A. Kumar,M. Kaur, S. Singh and A. Joseph, "High-temperature tribological studies of plasma-nitrided tool steels," Surface Engineering, vol. 32, pp. 620-633, 2018.

[3] D. Dragomir and D. Leontin, "The advantage of fluidized bed carburizing," Material Science and Engineering, vol. 302, pp. 9-115, 2001.

[4] H.W. Westeren, "Development of vacuum carburizing," Metallurgia and Metal Forming, vol 39, pp. 390-393, 1972.

[5] B. Edenhofer, W. Greafen, J. Meuller-Ziller, "Plasmacarburising - a surface heat treatment process for the new century," Surf Coating Technolgies, vol 144, pp. 34-225 2011.

M. Nikolussi, A. Leineweber and E.J. Mittemeijer, Growth of massive cementite layers; thermodynamic parameters and kinetics, Journal of Material Science, vol. 44, pp. 770-777, 2009.

J. Warnatz, R.W. Dibble and U. Maas, "Combustion: Physical and Chemical Fundamentals, Modelling and Simulation, Experiments, Pollutant Formation, Springer, 2001.

R.M. Souza, M. Ignat, C.E. Pinedo and A.P. Tschiptschin, "Structure and properties of low temperature plasma carburized austenitic stainless steels," Surface Coating Technologies, vol. 204 pp. 1102-1105, 2009.

[9] E. Franz-Josef, “An overview of performance characteristics, experiences and trends of aerospace engine bearings technologies," Chinese Journal of Aeronautics, vol. pp. 378384, 2007.

[10] Y. Yang, M.F. Yan, Y.X. Zhang, C.S. Zhang and X.A. Wang, "Self-lubricating and anticorrosion amorphous carbon/Fe3C composite coating on M50NiL steel by low temperature plasma carburizing" Surface Coating Technolgy, vol. 304 pp.142-149, 2016.

[11] H.K.D.H. Bhadeshia, "Steels for bearings," Progress in Material Science, vol. 57, pp. 268-435, 2012 .

[12] S.Ooi AND H.K.D.H. Bhadeshia, "Duplex hardening of steels for aeroengine bearings," ISIJ International, vol. 52, pp. 19271934, 2012.

[13] C. Jiang, B. Uberuaga and S. Srinivasan, "Point defect thermodynamics and diffusion in Fe3C: a first-principles study," Acta Materilia, vol. 56, pp. 3236-3244, 2008.

[14] J. Qua, J.Peter, P.J. Blaua, L. Zhang and H. Xuc, “ Effects of Multiple Treatments of low-temperature collosal supersaturation on Tribiological charateristics of Austentic stainless steels," Wear, vol. 265, pp.1909-1913, 2008.

[15] M. Hunkel, F. Hoffmann and H.W. Zoch, "Simulation of the heat treatment distortion of cylindrical shafts due to segregations in a carburizing steel grade," 3rd International Conference on Thermal Process Modelling and Simulation, Budapest, 2006, pp. 1-7.

[16] L. Amin, W. Chiristina and D. Didier, "Building an optimal hydrogen transportation system for mobility, focus on minimizing the cost of transportation via truck," Energy Procedia, vol. 142, pp. 2072-2079, 2017

[17] E.C. Marcoulaki, I.A. Papazoglou, N. Pixopoulou, "Integrated framework for the design of pipeline systems using stochastic optimisation and GIS tools," Chemical Engineering Research and Design, vol. 90, pp. 2209-2222, 2012.

[18] J.S. Pierre, "Recent developments in vacuum carburizing," Carburizing: Process Performance, vol. 9, pp. 9-31, 1989.

[19] K. Kubota, "Vacuum carburizing method and device, and carburized products," U.S. patent No. 5702540A, 702,540; $12,30,1997$

[20] P. Kula, R. Pietrasik and K. Dybowski, "Vacuum carburizing process optimization," Journal of Material Process Technologies, vol. 164-165, pp. 876-81, 2005.

[21] I. Ishigami, Y. Yokoyama, K. Miura, F. Uratani and H Hoshino, "Relationship between treating conditions and surface carbon concentration of low carbon steel vacuum-carburized with propane," Journal of Society of Materials Science Japan, vol. 49, pp. 41-1235, 2000

[22] R. Khan, S. Bajohr, F. Graf and R. Reimert, "Modeling of acetylene pyrolysis under steel vacuum carburizing conditions in a tubular flow reactor,' Molecules, vol. 12, pp. 290-296, 2007.

[23] T. Kruse, and P. Roth, "Kinetics of C2 Reactions during HighTemperature Pyrolysis of Acetylene," The Journal of Physical Chemistry A, vol. 101, pp. 2138-2146, 1997.

[24] R. Khan, S. Bajohr and D. Buchholz, "A Pyrolysis of propane under vacuum carburizing conditions: An experimental and modeling study," Journal of Analytical and Applied Pyrolysis, vol. 8, pp. 148-156, 2008

[25] C.A. Trujillo, F. Graf, S. Bajohr and R. Reimert, "Catalytic Treatment of Vacuum Carburizing Off Gas,"Chemical Engineering Technolology, vol. 29, pp. 390-394, 2006.

[26] K. Yada and O. Watanabe, "Reactive flow simulation of vacuum carburizing by acetylene gas," Computers and Fluids, vol. 79, pp. 65-76, 2013.

D. Mori, K. Yamada, Y. Hosokawa and M. Yamamoto, "Applications of electron probe microanalyzer for measurement of $\mathrm{Cl}$ concentration profile in concrete," Journal of Advanced Pharmaceutical Technologies and Research, vol. 4, pp. 83-369, 2006

[28] M. Zajusz, K. Tkacz-Śmiech and M. Danielewski, "Modeling of vacuum pulse carburizing of steel," Surface and Coatings Technology, vol. 258, pp. 646-651, 2014.

[29] P. Kula, R. Pietrasik and K. Dybowski, Vacum CarburizingProcess Optimization," Journal of Material Processing Technology, vol. 164, pp. 876-881, 2005.

[30] E. W. Korecka, “Modeling methods for gas quenching, low pressure carburizing and low pressure nitriding, Surface and Coating Technology, vol. 177, pp. 489-505, 2018.

[31] L. Liang, C. Hong, Y. Hao, S. Zhen and L. Zhu, "Study of M50NiL steel under carburizing and nitriding duplex treatment, Surface and Coating Technology, vol. 375, pp. 132-142, 2019.

[32] L. Cheng, Y. Xin, G. Tang, Z. Gyuan, S. Yang, T. Wang and L. Wang, "Characterization of carburized 14Cr14Co13Mo4 stainless steel by low pressure carburizing," Surface and Coating Technology, vol. 358, pp. 654-660, 2019.

[33] Y. Yanga, M.F. Yana, S.D. Zhanga, J.H. Guoa, S.S. Jianga, "Diffusion behavior of carbon and its hardening effect on plasma carburized M50NiL steel: Influences of treatment temperature and duration," Surface and coating technology, vol. 333, pp. 96-103, 2018 
Journal of Applied and Emerging Sciences Vol (09), Issue (02)

[34] M. Yan, Y. Wu and R. Liu, "Plasticity and ab initio characterizations on $\mathrm{Fe} 4 \mathrm{~N}$ produced on the surface of nanocrystallized $18 \mathrm{Ni}$-maraging steel plasma nitrided at lower temperature," Applied Surface Science, vol. 255, pp. 89028906, 2009.

[35] T. S. Lamim, Bernardelli, T. Bendo, C.H. Mello, C. Binder and A.N. Klein, "Duplex surface treatment of sintered iron by plasma nitriding and plasma carburizing at low temperature," Surface and Coating Technology, vol. 375, pp. 911-919, 2019.

[36] B. Wang, W.B. Xue, X. Jin, Y. Zhan, Z.L.Wu and Y.L. Li, “ Combined treatment plasma electrolytic carburizing and borocarburizing on Q235 low carbon steel," Material and Physical Chemistry, vol. 221, pp. 232-238, 2019.

[37] F. D. S. Severo, C.J. Scheuer, R.P. Cardoso and S.F. Brunatto, "Cavitation erosion resistance enhancement of martensite stainless steel via low-temperature plasma carburizing, Wear, vol. 428, pp. 162-166, 2019.

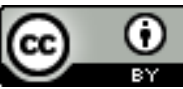

Journal of Applied and Emerging Sciences by BUITEMS is licensed under a Creative Commons Attribution 4.0 International License. 